\title{
Very low oxygen concentration in basal ice from Summit, Central Greenland
}

\author{
R. Souchez, L. Janssens and M. Lemmens \\ Département des Sciences de la Terre et de l'Environnement, Faculté des Sciences, Université de Bruxelles, Bruxelles \\ Belgium
}

\author{
B. Stauffer \\ Physikalisches Institut, Universität Bem, Switzerland
}

\begin{abstract}
Oxygen concentration as low as $3 \%$ has been detected in the basal silty ice of the GRIP core. Such values were never observed in ice from ice shects. They are most probably the consequence of organic matter oxidation in ice developed in a peaty deposit when the Greenland Ice Sheet was not present at the site. Flow-induced mixing has further incorporated this ice into glacier ice during the ice sheet build up. The part of the local ice component in the mixing process diminishes with the distance from the bed. This is the process which explains the oxygen profile.
\end{abstract}

\section{Introduction}

Polar glacier ice contains gas bubbles with an $\mathrm{O}_{2} / \mathrm{N}_{2}$ ratio very close to the atmospheric one which has a value of 0.268 or $\delta \mathrm{O}_{2} / \mathrm{N}_{2}=0$ if $\delta \mathrm{O}_{2} / \mathrm{N}_{2}$ is defined as $10^{3}\left[\left(\mathrm{O}_{2} / \mathrm{N}_{2}\right.\right.$ sample $/ \mathrm{O}_{2} / \mathrm{N}_{2}$ atmospheric air) -1 ]. This is the rule (or ice formed by sintering of dry firn. A slight enrichment could be present due to gravitational separation of gases in the firn if advection flow of gas caused by compression is minimal (Schwander, 1989; Craig et al., 1988). If percolation takes place and meltlayer ice is produced, then the situation changes. Due to the higher solubility of $\mathrm{O}_{2}$ compared to $\mathrm{N}_{2}$, air dissolved in water at $0^{\circ} \mathrm{C}$ has $0.56\left(\delta \mathrm{O}_{2} / \mathrm{N}_{2}=1089 \%\right)$ for the $\mathrm{O}_{2} / \mathrm{N}_{2}$ ratio. The meltwater, which is most probably saturated with air, penetrates into the firn and refreezes as a thin layer of ice covering cold snow grains. During refreezing, some of the dissolved gases escape by diffusion. $\mathrm{O}_{2}$ has a higher diffusion coefficient compared to $\mathrm{N}_{2}$ and is expected to be somewhat depleted in the melt-layer ice so that the $\mathrm{O}_{2} / \mathrm{N}_{2}$ ratio be lower than 0.56. Stauffer et al. (1982) have indeed found $\mathrm{O}_{2} / \mathrm{N}_{2}$ ratios in air extracted from melt-layer ice from the Dye 3 deep drilling in Greenland intermediate between 0.268 and 0.56 . In the same paper, these authors give results of two gas analyses from the basal silty ice found at the bottom of the Dye 3 drilling. $\mathrm{O}_{2} / \mathrm{N}_{2}$ ratios slightly lower than atmospheric ones are present : $0.260\left(8 \mathrm{O}_{2} / \mathrm{N}_{2}=-29.8 \%\right)$ and $0.262\left(8 \mathrm{O}_{2} / \mathrm{N}_{2}=\right.$ $-22.4 \%$ ). Slightly lower than atmospheric ratios have also been noted for glacier ice just above the basal sequence in West Greenland (Souchez et al., 1993) together with a depletion in $\mathrm{CO}_{2}$ concentrations which reach values as low as 81 ppmv. In this case, the following situation prevails. Water

\section{Copyright 1995 by the American Geophysical Union.}

Paper number 95GL01995 0094-8534/95/95GL-01995\$03.00 free of gases, for instance as a result of internal melting, comes into contact with atmospheric air enclosed in gas bubbles in the ice and drains into deeper layers, so that the gas phase in the ice will be depleted in components of higher solubility $\left(\mathrm{CO}_{2}\right.$, and also $\mathrm{O}_{2}$ compared to $\left.\mathrm{N}_{2}\right)$. Some of the basal ice in the same site of West Greenland is by contrast enriched in $\mathrm{CO}_{2}$ but is also slightly depleted in oxygen, a situation which was not investigated in detail.

In the basal silty ice from the GRIP core (Greenland Ice Core Project) in Central Greenland, oxygen concentration as low as $3 \%$ and $\mathrm{O}_{2} / \mathrm{N}_{2}$ ratios as low as $0.04\left(8 \mathrm{O}_{2} / \mathrm{N}_{2}=-851 \%\right.$ ) have been detected. Such values were never observed in ice from ice sheets. The aim of this paper is to try to understand such a gas chemistry.

\section{The context of the study}

The basal silty ice of $6 \mathrm{~m}$ thickness recovered at the base of the $3028.8 \mathrm{~m}$ long GRIP ice core was studied for its isotopic composition, both in $\delta D$ and $\delta^{18} \mathrm{O}$ (Souchez et al., 1994) and for its total gas content, $\mathrm{CO}_{2}$ and $\mathrm{CH}_{4}$ concentrations (Souchez et al., 1995). A detailed crystallographic study was also undertaken (Tison et al., 1994). The main results indicate that local ice formed at the ground surface in the absence of the Greenland Ice Sheet (GIS) is still present at the bottom but has been intimately mixed with glacier ice from the ice sheet at the centimeter scale during a build up of the GIS, possibly the original build up. The levels of $\mathrm{CO}_{2}$ and $\mathrm{CH}_{4}$ concentrations in the ice are extremely high : $130000 \mathrm{ppmv}^{\mathrm{CO}_{2}}$ and 6000 ppmv $\mathrm{CH}_{4}$ are the maximal values obtained at the bottom. The concentrations of these gases decrease upwards and reach atmospheric levels in the glacier ice just above the silty ice.

Environmental conditions at the base of the GRIP core, i.e. pressure of $3000 \mathrm{~m}$ of ice and temperature around $-9^{\circ} \mathrm{C}$, favour gas hydrate formation where the gases, instead of being in bubbles, are essentially concentrated within the solid framework of water molecules and possibly dissolved to a certain part in the ice. Such conditions only developed as a consequence of ice sheet growth but were not present at an carly stage of the existence of the basal ice. In the form of gas hydrates, the compounds under discussion are likely to be less affected by diffusion (Shoji and Langway, 1982) although Uchida et al. (1994) have shown that larger air hydrate crystals grow slowly in compensation for the disappearance of smaller crystals. $\mathrm{O}_{2}$ and $\mathrm{N}_{2}$ hydrates are less stable than other hydrates since their dissociation pressure is higher (Miller, 1969). The dissociation pressures at $0^{\circ} \mathrm{C}$ for the hydrates of oxygen and nitrogen are of the same order of 

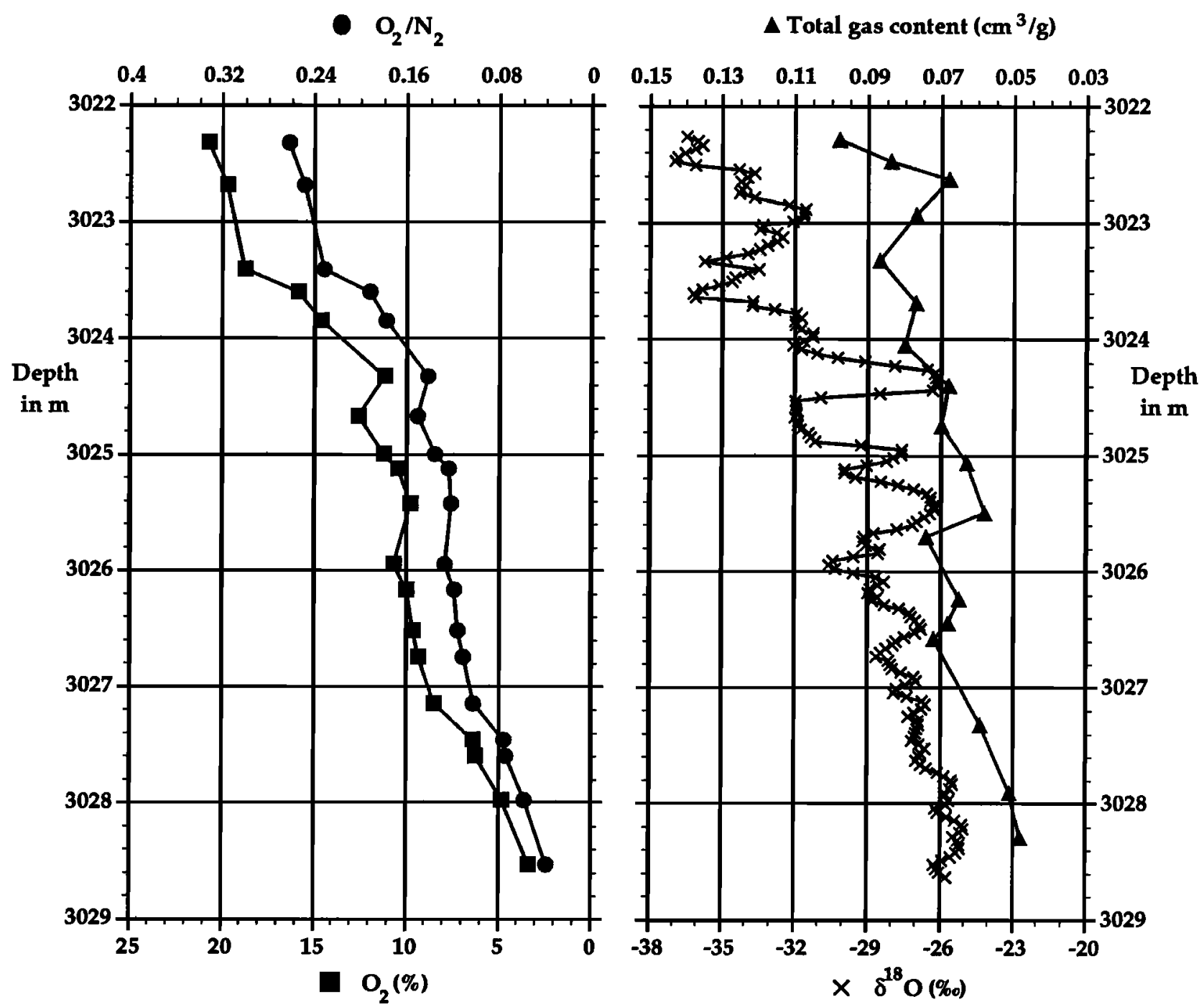

Figure 1. $\mathrm{O}_{2}, \mathrm{O}_{2} / \mathrm{N}_{2}, \delta^{18} \mathrm{O}$ and total gas content in the basal silty ice from the GRIP core.

magnitude (Davidson, 1975). It is thus considered here that the formation of air hydrates has not substantially modified the distribution of $\mathrm{O}_{2}$ relatively to $\mathrm{N}_{2}$ in the basal ice.

The gas composition analyses which have given the results discussed here, have been performed using a dry extraction technique with about a $80 \%$ efficiency in a cold room at $-20^{\circ} \mathrm{C}$ and a Varian 3300 gas chromatograph by a procedure similar to the one developed in Grenoble (Raynaud et al., 1982). A molecular sieve column and a thermal conductivity detector are used for $\mathrm{O}_{2}$ and $\mathrm{N}_{2}$. Different standard mixtures of $\mathrm{O}_{2}$ and $\mathrm{N}_{2}$ (prepared by the company L'oxhydrique) have been used to frame each sample in area counts because of the large concentration ranges. The precision of the measurements (r.s.d.) is $0.4 \%$ for $\mathrm{O}_{2}$ and $\mathrm{N}_{2}$.

\section{Results and discussion}

$\mathrm{O}_{2}$ and $\mathrm{O}_{2} / \mathrm{N}_{2}$ profiles are strikingly similar in the basal ice as shown in Fig.1. Because $\mathrm{N}_{2}$ is believed to be much less variable than $\mathrm{O}_{2}$, changes in the $\mathrm{O}_{2} / \mathrm{N}_{2}$ ratio should primarily reflect changes in $\mathrm{O}_{2}$ (Keeling and Shertz, 1992). Oxygen changes can thus be detected through changes in $\mathrm{\delta O}_{2} / \mathrm{N}_{2}$.

Figure 1 also shows a striking similarity between the $\delta^{18} \mathrm{O}$ profile and the $\mathrm{O}_{2} / \mathrm{N}_{2}$ profile in the basal ice. Higher $\mathrm{O}_{2} / \mathrm{N}_{2}$ are connected with lower $\delta^{18} \mathrm{O}$ values. There is a general decrease in $\mathrm{O}_{2} / \mathrm{N}_{2}$ from the top to the bottom of the sitly ice. Values as low as $0.04\left(8 \mathrm{O}_{2} / \mathrm{N}_{2}=-851 \%\right)$ are obtained at the base while values approaching those of the atmosphere are present at the top of the profile. Minima in the distribution are present at the level of the two major $\delta^{18} \mathrm{O}$ peaks in the middle of the profile. These $\delta^{18} \mathrm{O}$ peaks correspond to $\mathrm{CO}_{2}$ and $\mathrm{CH}_{4}$ peaks (Souchez et al., 1995). The profile of total gas content measured in Grenoble (Souchez et al., 1995) is also in the whole similar to the $\mathrm{O}_{2} / \mathrm{N}_{2}$ profile; the total gas content decreases in the basal ice from values close to normal ones for polar ice at the top (about $0.1 \mathrm{~cm}^{3} / \mathrm{g}$ ) to half of that amount at the bottom.

The very good negative correlation between $\mathrm{O}_{2}$ and $\mathrm{CO}_{2}$ (correlation coefficient -0.91 for 19 samples) seems to indicate an oxidation reaction of organic matter which, by using oxygen, is converted into $\mathrm{CO}_{2}$. The average $\mathrm{O}_{2} / \mathrm{CO}_{2}$ exchange ratio for the formation and destruction of terrestrial organic matter is considered to be 1.05 (Keeling and Shertz, 1992). Therefore, if the reaction occurred within the ice, the sum $\mathrm{O}_{2}+\mathrm{CO}_{2}$ must remain close to $21 \%$. As shown in figure 2 , this sum is far from $21 \%$ in the basal ice and decreases to a mininal value of $13 \%$ at the bottom of the profile. The 
methane present in the basal ice at a maximum concentration of $0.6 \%$ does not fundamentally change the picture. The insitu oxidation of organic matter within the ice is not a likely process to explain the oxygen distribution in the basal ice. Another possibility is the oxidation of organic matter which would be present undemeath the ice.

Is diffusion of oxygen from the ice to the subglacial ground, where it would be consumed, the process which could explain the oxygen profile in the basal ice? The controlling factor is the diffusion coefficient $D$ within the ice. The diffusion coefficient $D$ for oxygen in the ice is not well known. Neftel et al. (1983) studying the smoothing of an initial $\mathrm{CO}_{2}$ concentration in a melt layer by molecular diffusion considered three different values of $\mathrm{D}$ for $\mathrm{CO}_{2}: 310^{-14}$, $310^{-15}$ and $310^{-16} \mathrm{~m}^{2} \mathrm{~s}^{-1}$. Hemmingsen (1959) gave a value of $\mathrm{D}$ for $\mathrm{CO}_{2}$ equal to $710^{-14} \mathrm{~m}^{2} \mathrm{~s}^{-1}$ at $-9.5^{\circ} \mathrm{C}$ but was unable to detect permeation of oxygen through the ice. It is thought that the diffusion coefficient for oxygen be lower than that for carbon dioxide since $\mathrm{O}_{2}$ is less soluble than $\mathrm{CO}_{2}$ in the water film existing at the grain limits. An order of magnitude of $10^{-16} \mathrm{~m}^{2} \mathrm{~s}^{1}$ is probably an upper reasonable limit. Applying the second Fick's law, the $\mathrm{O}_{2}$ distribution in the ice can be computed, starting from an initial concentration $C_{0}$ at the distance $x=0$. The result indicates that diffusion will only take place over a distance of less than $0.5 \mathrm{~m}$ in $2.410^{6}$ years. A shorter time interval will of course reduce the distance over which the diffusion could have been active. Clearly, diffusion is unable to explain the situation. The similarity between a gas parameter $\left(\mathrm{O}_{2}\right.$ profile) and an ice parameter $\left(\delta^{18} \mathrm{O}\right.$ of the ice) is also a good argument against an explanation based only on diffusion.

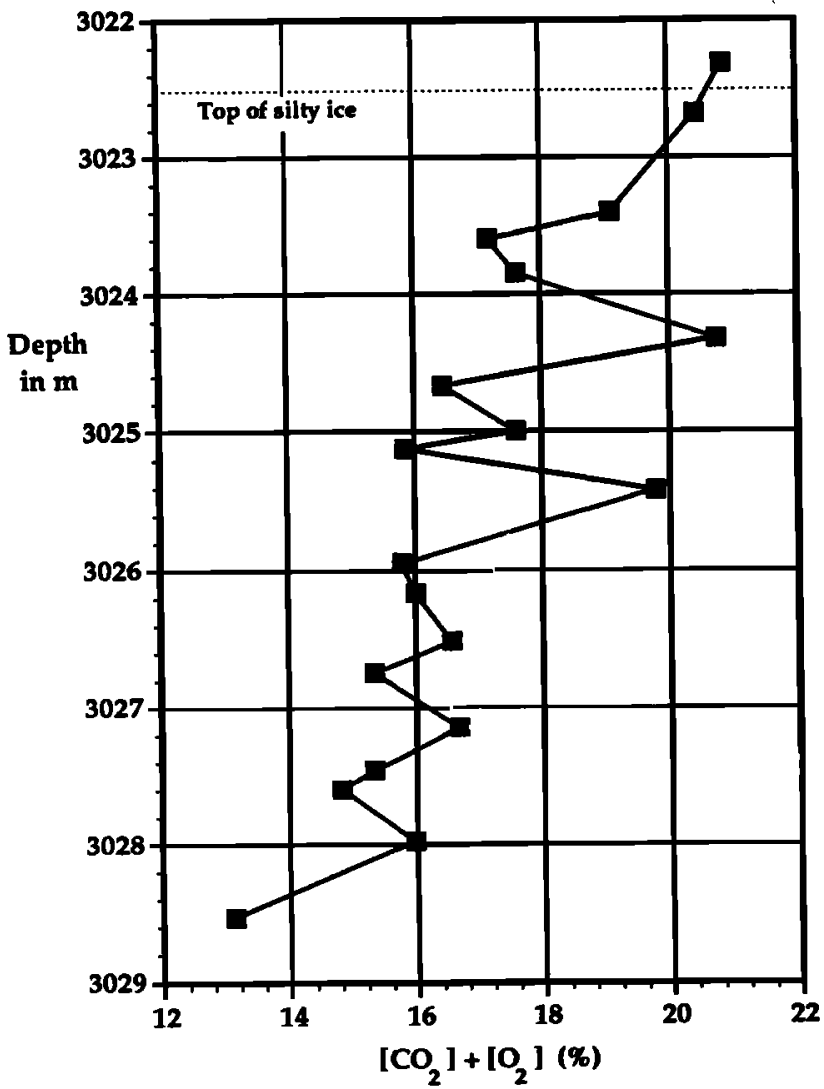

Figure 2. $\left[\mathrm{CO}_{2}\right]+\left[\mathrm{O}_{2}\right]$ in $\%$ versus depth in the basal silty ice from the GRIP core.

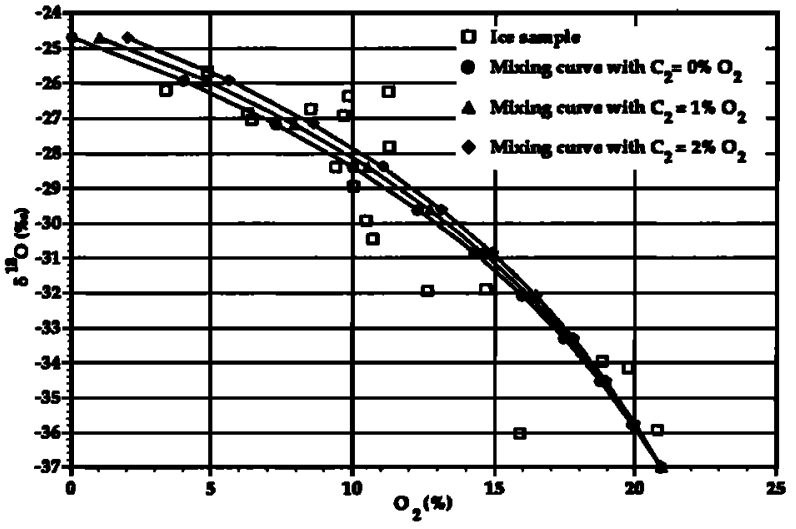

Figure 3. Mixing curves and ice samples from the basal silty ice of the GRIP core in a $\delta 180-\left[\mathrm{O}_{2}\right]$ diagram. The different points on the mixing curves represent 10 percent mixing ratio increments. The three different mixing curves correspond to $\left[\mathrm{O}_{2}\right]$ of the local ice component being respectively 0,1 and $2 \%$.

Another effect could produce negative $\delta_{2} \mathrm{O}_{2} / \mathrm{N}_{2}$ ratios. Differential capillary flow during loss of gas from the ice must be considered. Such an effusion of gases leads, in the simplest case when molecular interactions are neglected, to $8 \mathrm{O}_{2} / \mathrm{N}_{2}$ values simply proportional to the inverse $M^{1 / 2}$ ratio ( $M$ being the molecular mass) and to the amount of gas lost. Craig et al (1988) carried out experiments of vacuum pumping on ice samples to study gas losses. $8 \mathrm{O}_{2} / \mathrm{N}_{2}$ ratios as low as $-43.5 \%$ were obtained for the residual gases. Such values cannot be compared with the $\delta \mathrm{O}_{2} / \mathrm{N}_{2}$ ratios obtained in the GRIP basal ice which are much more negative. Therefore, effusion must also be excluded as a likely process to explain the $\mathrm{O}_{2}$ profile.

A mixing process between two end-members such as the one presented in Souchez et al. (1995) must also be considered here. Intimate mixing at the centimeter scale of glacier ice and local ice formed on the ground surface will lead to the situation described in figure 3. In this figure, the $\delta^{18} \mathrm{O}$ values of the ice in \%oo are plotted on the $y$-axis and the $\mathrm{O}_{2}$ concentrations in $\%$ on the $x$-axis. The black squares represent the different ice samples. The three different curves in fig. 3 are mixing lines calculated by using the equation :

$$
C=\frac{\left[M \cdot\left(C_{1} \cdot T_{1}\right)\right]+\left[(1-M) \cdot\left(C_{2} \cdot T_{2}\right)\right]}{M \cdot T_{1}+(1-M) \cdot T_{2}}
$$

$\mathrm{C}$ is the theoretical $\left[\mathrm{O}_{2}\right]$ in $\%$ for a given mixing ratio $\mathrm{M} . \mathrm{C}_{1}$ and $\mathrm{C}_{2}$ are the $\left[\mathrm{O}_{2}\right]$ in $\%$ of the two end-members; $\mathrm{T}_{1}$ and $\mathrm{T}_{2}$ their respective total $\mathrm{g}$ as content (in $\mathrm{cm}^{3} / \mathrm{g}$ ). Different values of $C$ are obtained for different mixing ratios $M$. Independently, $\delta^{18} \mathrm{O}$ values are calculated with the same mixing ratios from the $\delta^{18} \mathrm{O}$ values of the two end-members. $T_{1}, T_{2}, \delta^{18} \mathrm{O}_{(1)}$ and $d^{18} \mathrm{O}_{(2)}$ have the same values than those in Souchez et al. (1995), respectively for the glacier ice component and the local ice component. $C_{1}$ is taken as the oxygen concentration in atmospheric air $(20.95 \%)$ which is very close to the value measured in glacier ice just above the basal sequence. The three mixing curves in fig. 3 correspond to $\mathrm{C}_{2}$ values of respectively 0,1 and $2 \%$. It is clear that these curves match the distribution of the points representing the 
ice samples. Most of the points under the curves correspond to peaks in the $\mathrm{O}_{2}$ profile while most of the points above the curves correspond to minima in $\left[\mathrm{O}_{2}\right]$ in the profile. Such a situation can be easily explained if limited post-mixing diffusion has occurred in the ice : the peaks in the profile having seen their $\left[\mathrm{O}_{2}\right]$ reduced by this process while the neighbouring troughs are less pronounced since their $\left[\mathrm{O}_{2}\right]$ has increased.

The local ice component has thus a very low oxygen content, perhaps a total lack. Its $\left[\mathrm{CO}_{2}\right]$ and $\left[\mathrm{CH}_{4}\right]$ have been shown to be about 135.000 ppmv (Souchez et al., 1995) and 6300 ppmv respectively. Total gas reaches about one half of the normal content for polar glacier ice but this is not necessarily the consequence of an important gas loss since it is known that ice developed in the soil can have a highly variable gas content. The debris content in weight percent would be less than 0.3 , the value obtained at the base of the GRIP core being 0.2 . These characteristics fit with ice formed in a marshy anaerobic environment, eventually within a peat deposit in a permafrost environment. Such present-day analogues can be found for example in Alaska (Kvenvolden et al., 1993 ; Rasmussen et al., 1993). In situ oxidation of organic matter can provide a gas composition at the level of $135.000 \mathrm{ppmv} \mathrm{CO}_{2}$ if the ice contains about $3 \mu \mathrm{g}$ carbon $/ \mathrm{g}$ of ice which is quite possible. The lack of oxygen is in itself an indication of limited access to the atmospheric source.

\section{Conclusion}

Mixing at the centimeter scale in the bottom part of an ice sheet was identified at the GRIP site because of substantial production of $\mathrm{CO}_{2}$ and $\mathrm{CH}_{4}$ underneath the ice. Now, thanks to a study of the oxygen profile in the basal silty ice of the same core, this process is further documented. The very low oxygen concentration in the basal ice from the GRIP core is thus a strong argument to support such a mechanism of layer disruption.

Acknowledgments. This work is a contribution to the Greenland Ice Core Project (GRIP) organized by the European Science Foundation. We thank the GRIP participants and supporters for their cooperative effort. We also thank the national science foundations in Belgium, Denmark, France, Germany, Iceland, Italy, Switzerland and the United Kingdom, as well as the XII Directorale of the E.C. This paper is a contribution to the Belgian Global Change Program (Science Policy Office).

\section{References}

Craig, H., Y. Horibe, and T. Sowers, Gravitational separation of gases and isotopes in polar ice caps, Science, 242, 1675-1678, 1988.

Davidson, D.W., Clathrate hydrates, in Water: a comprehensive treatise, vol. 5, edited by F. Franks, 115-234, Plenum Press, New York, 1975.

Hemmingsen, E., Permeation of gases through ice, Tellus, 11, 355-359, 1959.
Keeling, R.F., and S.R. Shertz, Seasonal and interannual variations in atmospheric oxygen and implications for the global carbon cycle, Nature, 358, 723-727, 1992.

Kvenvolden, K.A., and T.D. Lorenson, Methane in permafrost preliminary results from coring at Fairbanks, Alaska, Chemosphere, 26, 1-4, 609-616, 1993.

Miller, S.L., Clathrate hydrates of air in Antarctic ice, Science, 165, 489-490, 1969.

Neftel, A., H. Oeschger, J. Schwander, and B.Stauffer, Carbon dioxide concentration in bubbles of natural cold ice, The Journal of Physical Chemistry, 87, 4116-4120, 1983.

Rasmussen, R.A., M.A.K. Khalil, and F. Moraes, Permafrost methane content : 1. Experimental data from sites in Northern Alaska. Chemosphere, 26, 1-4, 591-594, 1993.

Raynaud, D., R. Delmas, J.M. Ascencio, and M. Legrand, Gas extraction from polar ice cores : a critical issue for studying the evolution of atmospheric $\mathrm{CO}_{2}$ and ice-sheet surface elevation, Annals of Glaciology, 3, 265-268, 1982.

Schwander, J., The transformation of snow to ice and the occlusion of gases, in The Environmental Record in Glaciers and Ice Sheets, edited by. H. Oeschger and C. Langway, 53-67, J. Wiley, New York, 1989.

Shoji, H. and C.C. Langway, Air hydrate inclusions in fresh ice core, Nature, 298, 548-550, 1982.

Souchez, R., J.-L. Tison, R. Lorrain, M. Lemmens, and L. Janssens, Reconstruction of basal boundary conditions at the Greenland Ice Sheet margin from gas composition in the ice, Earth and Planetary Science Letters, 118, 327-333, 1993.

Souchez, R., J.-L. Tison, R. Lorrain, M. Lemmens, L. Janssens, M. Stievenard, J. Jouzel, A. Sveinbjörnsdottir, and S.J. Johnsen, Stable isotopes in the basal silty ice preserved in the Greenland Ice Sheet at Summit; environmental implications, Geophysical Research Letters, 21, 693-696, 1994.

Souchez, R., M. Lemmens, and J. Chappellaz, Flow-induced mixing in the GRIP basal ice deduced from the $\mathrm{CO}_{2}$ and $\mathrm{CH}_{4}$ records, Geophysical Research Letters, 22, 41-44, 1995.

Stauffer, B., A. Neftel, H. Oeschger, and J. Schwander, $\mathrm{CO}_{2}$ concentration in air extracted from Greenland ice samples, in Greenland ice core : geophysics, geochemistry and the environment, edited by C. Langway, H. Oeachger and W. Dansgaard, 85-89, American Geophysical Union, Geophysical Monograph 33, Washington, DC, 1982.

Tison, J.-L., T. Thorsteinsson, R. Lorrain, and J. Kipfstuhl, Origin and development of textures and fabrics in basal ice at Summit, Central Greenland, Earth and Planelary Science Letters, 125 (1-4), 421-437, 1994.

Uchida, T., T. Hondoh, S. Mae, V. Lipenkov, and P. Duval, Air-hydrale crystals in deep ice-core samples from Vostok Station, Antanctica, $J$. of Glaciol., 40 (134), 79-86, 1994.

R. Souchez, L. Janssens, M. Lemmens, Departement des Sciences de la Terre et de l'Environnement, Faculté des Sciences CP 160/03, Université de Bruxelles, B-1050 Bruxelles, Belgium. (email: glaciol@is1.ulb.ac.be)

B. Staufer, Physikalisches Institut, Universität Bem, Switzerland

( Received May 12, 1995; accepted June 16, 1995.) 